\title{
Unified theory of firm: an empirical analysis
}

\author{
Jarita Duasa \\ Department of Economics, International Islamic University Malaysia, \\ Kuala Lumpur, Malaysia, and \\ Suhaimi Mhd Sarif and Nur Arfifah Abdul Sabian \\ Department of Business Administration, \\ International Islamic University Malaysia, Kuala Lumpur, Malaysia
}

\begin{abstract}
Purpose - Four main strategies required for firms to be able to achieve their main objectives in organizations under the unified theory of the firm are technological advance, intellectual development, spirituality conducts and customer satisfaction concern. This study aims to explore the inclination of firms to adopt all these strategies in, factors that contribute to the adoption of all these strategies and significant relationship between these strategies of firms in the context of Malaysian firms.
\end{abstract}

Design/methodology/approach - Using primary data from the survey on a sample of firms in the financial sector of Malaysia, the study adopts several methods of analysis such as $t$-test for dependent sample, $t$-test for independent sample and correlation. Furthermore, ordinary least squares regressions are estimated to determine factors that have an impact on a particular strategy.

Findings - It is found that the strategies of the unified theory of the firm significantly contributed to the education level of managers. Highly educated managers tend to adopt strategies most of the time. It is also found that scores of customer satisfaction concern are highly related to scores of intellectual development and spirituality conduct. The correlation coefficient is also high between spirituality conduct and intellectual development.

Originality/value - The study analyzes the adoption of important strategies of a unified theory of firm among several firms using first-hand data (primary data) collected from the survey.

Keywords Malaysia, Ordinary least squares regression, OLS regression, Spiritual dimension, Unified theory of firms

Paper type Research paper

\section{Introduction}

The conventional approach of the theory of the firm is missing to accomplish human liveliness. The market-based theory of the firm focuses on the industrial-organizational practitioners which are deficient of self-motivated (dynamism). The evolutionary approach toward the resource-based and knowledge-based of the theory of the firm is also unable to provide self-motivated (dynamism) due to the lacks of theology fundamental to uphold the needs of scholarly intellectual involvement from stakeholders.

The introductory of theories of the firm has been developed by Coase (1937). At this time, the industrial era was developing and Coase's theories of the firm were followed by other theories such as theories of agency, property rights and finance to develop the theory of ownership. However, Coase (1937) found serious flaws in these theories as they were unable to clearly define the nature and the boundaries of firms because transaction cost of coordinating production through market exchange, given imperfect information, is greater than within the firm. Besides, the internal structure of the firm was not clearly and formally
Received 14 September 2018 Revised 11 June 2019 Accepted 21 July 2019

\footnotetext{
Journal of Islamic Accounting and Business Research c Emerald Publishing Limited (c) Emerald Publishing Limited DOI 10.1108/JIABR-09-2018-0143
} 
organized in terms of the production, incentives, controls and internal hierarchies. Moreover, the relationship between firms and market are not clearly defined whether firms are substitutes for the market or firms are not market but players with some limitations. Due to these factors, Coase $(1960,1988)$ brought the idea that the firm is an economic entity that provides incentives and structure to solve organization coordination. Furthermore, the firm is considered as a collection of assets and incentive mechanisms and a collection of capabilities of the past.

Besides, Kay (1992) explained that the early theory of the firm is not a unified theory due to the bounded rationality approach that made the roles of entrepreneurs become uncertainty. Nelson and Winter (1982); Kogut and Zander (1996) and Langlois and Garrouste (1997) also believed theories of the firm are unable to offer a unified theory of firm due to lack of learning processes both at the individual and organizational level. The alternative theories identified later are based on evolutionary theory and the resource-based view of the firm. Garrouste and Saussier (2005) found that resource-based view and knowledge-basedview of theories of the firm are more unified and comprehensive compare to theories of the firm due to:

- knowledge is the result of learning and experience;

- context (local) and path-dependent (historical) partly tacit; and

- organization is partly unaware of its existence as it embedded in organizational routines and individual skills.

Resource-based view and knowledge-based view of the theory of firm offer a unified theory of the firm based on evolutionary perspectives. However, given the background of the contemporary business world that is full of uncertainty as a result of globalization process, rapid changes are rampant due to the fast-paced technological development, high mobility of society and high intensity in the competition (Mahutga and Smith, 2011; Vergragt, 2012). Karim and Hussein (2008) defined that evolutionary perspectives emphasize the importance of knowledge and innovation to achieve sustainable competitive advantage. Liu et al. (2004) emphasize that this situation makes the business world more competitive due to the increasing number of enterprises that are competing on the uniqueness.

Emphasis on the importance of Islamic approaches toward theories of the firm is now growing. It is fast becoming a new market force and now is moving into the mainstream market, affecting and changing the perception of how theories of the firm should be conducted in following Shariah rules and regulations. Lewis (2006) said firm gains and sustains competitive advantage when it imbrues with soul (spirituality). Osman-Gani and Sarif (2011) mentioned that excellence in spirituality (soul) leads to better worldview farsighted and continuous improvement guided by commendable values. Hassan (2010) highlighted the integrated Islamic approach toward theories of the firm can be enhanced to gain and sustain competitive advantage via Islamic approaches. It could create betterment of mankind and a balanced community. This unified theory of the firm is necessary to provide insights for rigorous, dynamic and comprehensive strategic management analyses to achieve organizational sustainable innovation and competitive advantage. The knowledge-based view offers an integrative framework to achieve sustainable knowledge management and organizational learning that is driven by a knowledge-based view of firm innovation. The knowledge-based view with spirituality foundation is expected to sustain intellectual contributions from knowledge workers.

The Tawhidic Paradigm for the theory of the firm (unified theory of firm) contributes to the Islamization of Knowledge (IOK) agenda. The primary concern of the Islamization of 
knowledge focuses on the epistemological and methodological emphasis. Aslam (2005) contended that the root cause of all problems as that of knowledge has been interpreted by the Western world through methodologies that are not in line with the Islamic worldview of firm particularly its epistemological foundation. The concept of worldview very much related to the (IOK) agenda. At-Attas (1995) defined worldview as the vision of reality and truth that appears before our mind's eyes revealing what existence is all about, represented by the phrase ru'yat al Islam li al-wujud. At-Attas (1995) reminded readers that the process of IOK is "conceptual" in nature which is present to the intellect, and hence, referred to as being in the mind. Faruqi (1982) viewed IOK as the process of recasting knowledge according to the Islamic principles. According to Aslam (2005), both Al-Attas and Al-Faruqi referred to the worldview or framework where contemporary knowledge is interpreted and presented.

Tawhidic Paradigm itself can be understood as a set of beliefs that acknowledges the Oneness of Allah SWT (Monotheism) in everything regardless of time, space and place. One of the main sources of Tawhid reference comes from the classical literature written by Shaykhul Islam Muhammad Ibn 'Abdul Wahhab who was born in Al-Uyaynah near Riyadh in 115 A.H. Fawzan (2005) mentioned there are two keywords and phrases that can be extracted from the stated verse namely, Tawhid and 'Ibadah (worship). He defined Tawhid as the devotion of one's acts of worship to Allah alone and 'Ibadah as surrender or submission. Technically, Ibadah refers to all acts of devotion including sayings, apparent and hidden deeds, which bring about Allah's pleasure. Mohd Kamal Hassan (2010) defined Tawhidic Paradigm as being about Islamic monotheism thinking to serve as the true servant of Allah ('ibad al-Rahman), vicegerents (khulafa' fi al-ard), true believers (al-mu'minun) for the sake of the betterment of mankind (khayra ummatin ukhrijat lil-Nas) (Qur'an,3:110) and 'balanced community' (ummatan wasatan li-takunu shuhada' 'ala al-nas) (Qur'an, 2:143) (2010, p. 187). The objectives of Syariah (Maqasid Syariah) in regard to the Tawhidic paradigm is to provide the horizontal dimension equity (justice equilibrium). Ahmad (1980), Siddiqi (1981), Naqvi (1981), Ariff (1989), Chapra (1992), El-Ghazali (1994) and Sirageldin (2002) concluded the elements of Tawhidic paradigm as:

- Tawhid (unity), indicates the vertical dimension of the Islamic ethical system;

- $A l-' A d l$ (justice equilibrium);

- Ikhtiyar (free-will) that provides individual opportunities to choose in the economic system; Fard (responsibility) implies that individuals and society need to uphold public good;

- Rububiyyah indicates divine arrangements for nourishment, sustenance and directing things toward their perfection;

- Tazkiyah calls for growth with purification that should incorporate the good of others and be conducted with ethical and moral considerations; and

- Khilafah indicates an individual's role as God's vicegerent on earth.

Tawhidic Paradigm can be integrated into the Theory of the Firm based on the foundation of Islamic faith which is kalima shahaada, which implies, to recognize Allah as the only universal God and Prophet Muhammad (Peace Be Upon Him) as the messenger of Allah. According to this foundation, the ultimate aim of the Islamic management system is to gain the pleasure of Allah by executing all duties prescribed by Him. Those duties include all the strategies of firms such as technological advance, intellectual development, spirituality conducts and customer satisfaction concern. The development of a unified theory of the firm is in line with the main reason of the creation of man, to worship ('ibadat) Allah, by which it has to be performed with trust and justice as depicted in Figure 1 and is consistent with the job description of vicegerent 


\section{JIABR}

Figure 1.

Fundamental principles of DuniawiUkhrawi view

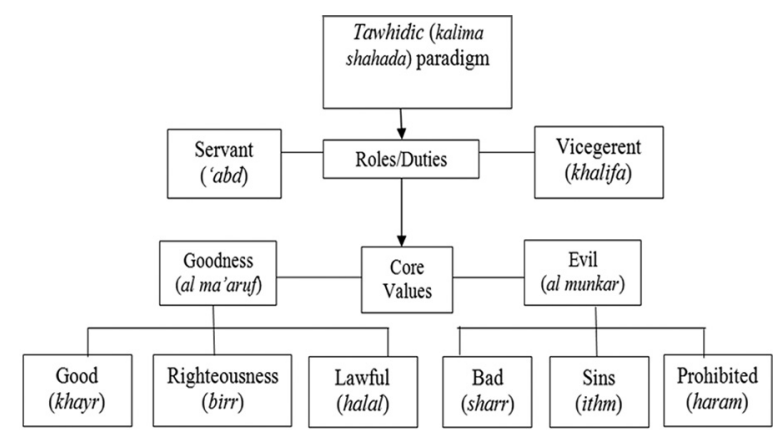

Source: Ismail and Sarif (2011)

(khalifa) as stated in Surah al Baqara, 2:30. This goes in parallel with the purpose of the creation of mankind to be Allah's servant and also His vicegerent on earth.

Thus, basically, four main strategies required for firms to be able to achieve their main objectives in organizations under the unified theory of the firm: technological advance, intellectual development, spirituality conducts and customer satisfaction concern. While a lot of studies have been looking at the impact of the said strategies on firms' performance, a study to analyze factors contributing to the adoption of these strategies in firms is very scanty. The present study attempts to close this gap and explore the inclination of firms to adopt these strategies and to analyze factors that contribute to the adoption of the strategies and significant relationships between the strategies of firms in the context of Malaysian firms, particularly in the financial sector.

\section{Literature review}

The topic of theories of the firm caught the attention of many scholars recently especially on the issue of the spiritual dimension in determining the efficiency and performance of firms. Many past studies were basically based on various approaches such as resource approach, knowledge approach and others where they reported different results and arguments.

The performance of the firm is defined as "a state of competitiveness of the organization, reached through a level of efficiency and productivity which ensure a sustainable market presence" (Boulescu et al., 2002). It means that performance relies on utilization, optimum, competitive, efficiency and productivity to generate a successful organization. The economic theory also believes that profit maximization can be achieved with a great performance by using the minimal cost of production. Therefore, the concept of the theory of the firm has been subscribed to designate the nature of the firm, the boundaries of organizational environment, internal and external factors of the organization so as to formulate and implement the sustainability of the business, business continuity and competitive advantages strategies. Birger (1984) develops the effectiveness of analyzing a firm's resource position and to look at some strategic options which naturally surface from the resource perspective, in particular, to the relationship between profitability and resources. The effectiveness of the firm can be measured through analyzing resources for high returns and it also has strong influences such as machine capacity, customer loyalty, production experience and technological leads. Therefore, those components such as machine capacity, customer loyalty, production experience and technological lead firm performances to be more successful and developed. Besides, Sarah et al. (2001) review the history of debate on 
knowledge and the firm, current contribution to the knowledge-based theories of the firm in strategic management, provides an integrated model or knowledge-based view of the firm and its implication. An integrated knowledge-based view of the firm links knowledge, capabilities and competitive advantage, which influences firm performances. However, they believe theories of the firm are contested and unmapped terrain, no unified and clear-cut theory, partially contributed between methodological individualism or social-psychological identity theory and the concepts and relationships vary considerably.

According to Coase (1937), firms exist due to effectiveness use price mechanisms to discover relevant information and to negotiate contracts. Firms have lower costs as some authority can direct resources more efficiently and control the terms of trade. Coase (1937) defines the main tasks of theory of the firm as to discover why firm emerges in specialized exchange economy, such as the existence of firm, to study forces, which determine size of firm such as boundaries of firm and to inquire into diminishing returns to management such as internal organization of firm. Walker (2008) argues that the mainstream approaches to the theory of the firm do not provide a theory of the human capital based or knowledge-based firm. It examines the neoclassical theory of the firm, the transaction cost model, the incentive-system approach and the Grossman Hart Moore approach to the firm and argues that none of them are able to fully capture the changes to the firm that the movement toward a knowledge economy entails. Based on incentive-system theory, the technology of production depends on the agent's chosen (employees of firm) and physical capital (machine) to earn a greater total surplus. Oppositely, the Grossman Hart Moore approach mentioned that the theory of the firm is built from human capital (information, knowledge), non-human capital (control right over ownership, nature of authority) and ownership (machinery, inventories, buildings, patents, client list and firm's reputation).

Having said that the spiritual dimension in theory of the firm was lacking, Akhtar (1993) studies both physical and moral factors instruments in causing the economic growth in an Islamic economy compared to the conventional economy which viewed in terms of physical factors only. Besides, this study discusses the role of moral factors for the sake of the bounty of Allah. There was a theoretical framework developed to support their objective. Quran and Sunnah are used to support their reasoning. Besides, the contribution of physical and moral factors in economic growth is explained by using the aggregate production function with the application on contemporary Muslim countries. Many scholars realize the importance of spirituality, and that it has to apply in the business world (examples of Lewis, 2006 and Aziz, 2015). Various studies have been conducted in business ethics to fill this gap, for example, the latest book edited by Zsolnai (2015) focuses on the new perspectives and findings of a firm's sustainability-related spirituality from the economic and social point of view. This book gives a vast contribution to the business world by highlighting the ideas and initiatives that encourage ethical business practices and promote policies to ensure sustainability.

Hasan (2002) highlights on the maximization of profit in Islamic economics, which is considered as a good practice as long as not overrule the "Syariah" (Islamic law). The ontology in business in today's world is shifted from just focusing on profit maximization to more value-added objectives. In general, many studies are looking at changing behavior of customers in terms of satisfaction level from any strategy of the firm which later relates to profit maximization. The higher satisfaction gained by customers will generate higher profits. The epistemology in this study benefits entrepreneurs, government, students, universities, policymakers, marketers and organizations. The view on the methodological perspective using the role of nature for maximization postulates the concerns on both profit and consumer utility as a mainstream of economics to maximize firm desire profit. Foss (2000) defines the behavior of a firm related to the internal structure and ownership 
structure. He highlighted the neoclassical theory that ownership and institutions neither affect the objective of firm nor its knowledge base, technology nor cost efficiency. Park and Shin (2004) believes the performance of the firm depends on technological advance, intellectual development and spirituality. Walker (2008) said that technological advance enhances the performance of firm by using incentive-system theory. Sarah et al. (2001) mentioned that knowledge or intellectual development is also a main component to generate firm's performances while Hassan (2002) stresses the importance of customers' satisfaction in enhancing profitability of firm.

Focusing on Malaysian firms, a study conducted by Sarif (2013) has proven that there is the influence of Tawhidic paradigm on the development of a unified theory of the Firm. The study was conducted among 15 senior managers of Islamic financial institutions listed on Bursa Malaysia, where it was found that the Tawhidic paradigm fastens the nature of the firm including the process and the functional area of the firm to make sure it survives and sustains with good universal values. Furthermore, the study contends the vision, mission and objective statements which reflect that the Shar' ${ }^{-}$ah-compliant companies did apply the Tawhidic paradigm for continuous improvement in many aspects such as functional aspects, services to the stakeholder and the social welfare of humanity (Sarif, 2013). Tawhidic Paradigm have a great influence on business firms. Another recent study conducted by Sarif et al. (2013) on "The influence of Tawhidic Paradigm in Managing Firms for Sustainable Competitive Advantage: A Malaysian Case" found that the influence of Tawhidic Paradigm on organizational goals and objectives, as well as organizational knowledge and innovation is high. These findings are based on the data collected from 242 public listed companies on the main board of Bursa Malaysia.

Tsafe and Rahman (2013) explore and analyze the extent Shariah spirituality dimensions explain board service performance in Malaysian microfinance institutions. Data have been obtained from 63 responses to the questionnaire in 4 microfinance organizations. The research findings of determining the extent Shariah spiritual values explain board service performance show the significance of governance mechanism in firms' development process. Another study by Grine et al. (2015) explores the influence of Islamic spirituality on Muslim women's entrepreneurship in Malaysia, showing the effects of spirituality on their careers, business ventures and general entrepreneurial behavior. The findings highlight the position and key role of spirituality in the success of Muslim female entrepreneurs. This study underscores not only the religious compatibility between work and women success but also highlights significant prospects for the untapped societal potential of Muslim women, in light of their spiritually-backed competencies, and with respect to harnessing their creative and entrepreneurial talents. This study reinforces the connection with God as a common denominator to the definition of spirituality and further shows that spirituality plays a significant role in the prioritizing of the needs of family and life, motivation, social responsibility and decision-making of Muslim women entrepreneurs in Malaysia. Interestingly, Abdul Rahman and Shamsuddin (2017) examine the influence of spiritual capital (SpC) in improving the corporate governance (CG) practices in Malaysian businesses particularly the GLCs (government-linked companies). SpC is classified as the vital fourth component of intellectual capital. SpC governs how the other three capitals (human capital, structural capital and customer capital) should be used. This conceptual paper discusses the functions of $\mathrm{SpC}$ in enhancing the CG practices in the GLCs. Nonetheless, Djafri and Noordin (2017) examine the impact of the dimensions of workplace spirituality on agents' organizational commitment in Islamic insurance (Takaful) industry in Malaysia. This study used a positivist research approach, comprising a quantitative basis of inquiry and gathered data via survey questionnaires. Pearson's correlation and stepwise multiple regression 
analyses were used to analyze the data. The findings indicated that spirituality in the workplace has a positive and significant effect on organizational commitment. The relationship between each and every component of workplace spirituality and organizational commitment was found to be substantial, positive and significant.

As of intellectual development, similar to the strategy of spirituality conducts, many studies have been looking at the impact of intellectual development strategy on the performance of firms rather than exploring the determinants of intellectual development itself within firms. Lee and Mohammed (2014), for example, investigate the intellectual capital impact on agricultural firms' performance listed on the Malaysian Stock Exchange during 2003-2009. Panel regressions' results showed that a firm's intellectual capital has a positive impact on financial and productivity performances. However, the association between intellectual capital and economic performance is insignificant. Bontis et al. (2000) empirically investigate the three elements of intellectual capital, i.e. human capital, structural capital and customer capital, and their inter-relationships within two industry sectors in Malaysia. The study was conducted using a psychometrically validated questionnaire which was originally administered in Canada. The main conclusions from this particular study are that: human capital is important regardless of industry type; human capital has a greater influence on how a business should be structured in non-service industries compared to service industries; customer capital has a significant influence over structural capital irrespective of industry; and finally, the development of structural capital has a positive relationship with business performance regardless of industry. In sum, the study shows that intellectual capital has a significant and substantive relationship with business performance regardless of the industry sector. Nevertheless, the association between knowledge issues and firm performance has received attention in other similar domains, such as knowledge management (KM) practices (Palacios Marqués and GarrigósSimón, 2006; Andreeva and Kianto, 2012). However, as the current intangible resources such as intellectual capital (IC) is popularly discussed recently on its influence on firm performance, empirical IC research seems to have a truly global presence. Several studies have focused mainly on European and Asian companies and some papers have examined IC and firm performance in North and South American, African and Middle Eastern firms. According to Inkinen (2015), the most actively studied companies have been Taiwanese (12), Spanish (9) and American (5) firms. This indicates that the line of research is no longer dominated by American and British academics, as it was until the early 2000s.

As for the technological advance, several studies have been looking at the influence of information technology (IT) acceptance on organizational agility (such as Mohamed Zainal et al., 2015), impact of accounting information system on firm performance of Malaysian SMEs (such as Kharuddin et al., 2010) and the impact of e-commerce usage on business performance in the tourism sector (such as Mohamed et al., 2009). Mohamed Zainal et al. (2015) found that actual system or technology usage had the strongest direct effect on organizational agility among managers and executives in manufacturing firms in Malaysia. Meanwhile, perceived usefulness and perceived ease of use of IT influenced organizational agility indirectly through actual systems or technology use and attitudes toward using the technology. Kharuddin et al. (2010) found that Malaysian SMEs adopting accounting information systems show significant improvement in performance compared to nonadopters. Mohamed et al. (2009) indicate that technology competency, firm size, firm scope, web-technology investment, pressure intensity and back-end usage have a significant influence on e-commerce usage. Among these variables, back-end integration is found to function as a mediator. E-commerce experience (in years) is found to moderate the relationship between e-commerce usage and business performance. 
With regard to consumer satisfaction strategy, previous research has explored the relationship between customer attitudes and business performance broadly (Bernhardt et al., 2000; Anderson and Sullivan, 1993; Kerin et al., 1990; Reichheld and Sasser, 1990; Morgan and Rego, 2006; Reichheld and Teal, 1996). Some findings conclude that higher customer satisfaction leads to higher levels of repurchase intent, customer advocacy and customer retention (Anderson and Sullivan, 1993; Bolton and Drew, 1991; Lam et al., 2004; Mittal and Kamakura, 2001). Nonetheless, higher satisfaction and loyalty lead to improved revenue, profitability and cash flows (Reichheld and Teal, 1996; Ittner and Larcker, 1998; Heskett et al., 1994).

This study differs from previous literature in two significant ways. First, we aim to analyze factors contributing to the adoption of these strategies of intellectual development, technological advance, spiritual conducts and consumer satisfaction concern by firms. Most of the previous studies were mainly focusing on the impact of these strategies of technological advance, intellectual development, spirituality and customer satisfaction on the performance of firms rather than exploring on determinants of the adopted strategies. Second, empirical studies on the unified theory of firms particularly of Malaysian firms are found to be very limited. In particular, the study on the determinants of firms' strategies is almost none in the context of Malaysia.

\section{Data and methodology}

\section{a. Data}

To analyze factors contribute to the adoption of strategies by firms, the present study is using a survey to collect primary data from the target respondents, i.e. firms. In the actual field study, 200 questionnaires are randomly distributed to public listed companies' managers in the financial sector of Malaysia. The study is able to collect completed 85 responses from the distributed number.

\section{b. Questionnaire design}

A set of questions are developed with regard to the possible four strategies adopted by firms in the organizations (technological advance, intellectual development, spirituality conducts and customer satisfaction concern). Data collected for these strategies/constructs are based on the responses of the representative of organization/firm on the sets of questions provided with the answers in form of Likert scale, that is, Never, Rarely, Slightly, Sometimes, Usually and Always. Response that has lower value indicates that the strategy is hardly or not being conducted and the response that has higher value indicates that the strategy is strongly adopted. The number of items/questions of each strategy/construct is displayed in Table I.

According to Cavana et al. (2001), a questionnaire should be piloted with a reasonable sample of respondents who come from the target population or who closely resemble the

Table I.

\begin{tabular}{llc}
\hline Variable/construct & No. of item in scale & Cronbach's alpha \\
\hline$B$ & 7 items & 0.901 \\
Technological advance & & \\
$C$ & 16 items & 0.942 \\
Intellectual development & & 0.919 \\
$D$ & 20 items & 0.943 \\
Spirituality conduct & & \\
$E$ & 10 items & \\
Customer satisfaction concern & &
\end{tabular}

Reliability test on pilot data

Customer satisfaction concern 
target population. A total of 30 respondents were chosen for the pilot test randomly among public listed companies' managers in order to determine the reliability to measure the variables for this research before performing data collection to achieve the objectives. In of firm total, 30 sets of questionnaires were distributed to a few public listed companies' managers to ensure that all the items were rightly measured and the respondents have understood the questions. The suggestions received were then incorporated back into the questionnaire to improve the clarity and validity of the items.

Validity. Validity is defined as how much any measuring instrument measures what it is intended to measure. Bryman and Bell (2003) also suggested that the important issue of measurement validity relates to whether measures of concepts really measure the concept. In other words, "validity" refers to the issue of whether an indicator (or set of indicators) that is devised to gauge a concept really measures that concept. There are a number of different measures that can be used to validate tests. In the classical model of test validity, construct validity is one of three main types of validity evidence, alongside content validity and criterion validity (Guion, 1980). In this study, construct validity has been used. Construct validity is the appropriateness of inferences made on the basis of observations or measurements, specifically whether a test measures the intended construct. Constructs are abstractions that are deliberately created by researchers in order to conceptualize the latent variable, which is correlated with scores on a given measure (although it is not directly observable). Construct validity examines the question: Does the measure behave like the theory says a measure of that construct should behave?

Reliability. The present study uses reliability to test the internal consistency among the variables or items through a summated scale (Hair et al., 2006). The most widely used test for internal consistency reliability is Cronbach's coefficient alpha (Cronbach, 1946). Given the scales of items for a construct, the Cronbach's alphas are calculated to assess the reliability of those items. For construct with alpha under a certain threshold (0.9 in this report), items within each construct are to be checked in order to ensure that the items have high correlations. According to Cavana et al. (2001), the reliability measures the extent to which the concept measurement is without bias (error-free). The reliability of a measure indicated the stability and consistency, in which the instrument measures the concept and helps to assess the goodness of a measure. Consistency reliability or Cronbach's alpha measures how well a set of items (or variables). Cronbach's Alpha is computed in terms of the average intercorrelations among items that measuring the concept. The closer the reliability coefficient to 1.0, the better.

Results in Table I indicate high values of Cronbach's alpha (reliability test coefficient) ranging from 0.901 to 0.943 for all four constructs. Norusis (2002) quoted that good scales have values larger than 0.8. The results show high values of Cronbach's Alpha which indicates that all the constructs are measuring the concepts, thus suggesting that the instrument is reliable.

\section{c. Methodology}

The responses from the survey are analyzed using several methods. Descriptive measures such as frequencies, proportions and mean are used to provide a general summary of the findings. To determine differences between groups, $t$-test for dependent sample and $t$-test for independent sample are applied for variables having two groups/categories. The pairedsamples $t$-test or $t$-test for dependent sample compares the means of two variables for a single group. It computes the differences between values of the two variables for each case and tests whether the average differs from 0 . The independent-sample $t$-test procedure compares means for two groups of cases. Ideally, for this test, the subjects should be 
randomly assigned to two groups, so that any difference in response is due to the treatment (or lack of treatment) and not to other factors.

For more in-depth analyses, ordinary least squares (OLS) regressions (multiple regression) are estimated to determine factors that may have an impact on a particular variable. This method adopted is in line with the current objective of this study that is to analyze factors contributing to the adoption of strategies by firms. In most past studies, a similar method is normally adopted to analyze the impact of strategies or other factors on the performance of firms. However, this method is rarely applied to investigate the determinants or factors affect the adopted strategies by firms.

The hypotheses that would like to be tested are as following:

Ho. Duration of firm establishment, firm based practice and background of the manager (age, education, working experience, monthly income, marital status, job position, ethnicity) do not significantly affect the adoption of each strategy (technological advance, intellectual development, spiritual conduct and customer satisfaction concern).

Ha. Duration of firm establishment, firm based practice and background of the manager (age, education, working experience, monthly income, marital status, job position, ethnicity) are significantly affect the adoption of each strategy (technological advance, intellectual development, spiritual conduct and customer satisfaction concern).

Four models are developed in this analysis with the dependent variable in each model represents each strategy/characteristic of the firm, namely, "technological advance," "intellectual development," "spirituality conducts" and "customer satisfaction concern." The regressors (independent variables) or expected factors that contribute to the adoption of strategy are duration of company establishment, the based practice of company (Islamic or conventional), as well as manager's background such as education level, marital status, gender, years of working experience, religion, ethnicity, income level, age and job position. Most independent variables/data are in scale and some of them are converted into dummy variables such as marital status, gender and ethnicity.

The four models developed are as following:

$$
\begin{aligned}
(\text { technological advance })_{i}= & \beta_{0}+\beta_{1}(\text { durationestablishment })_{i}+\beta_{2}(\text { dummy_practice })_{i} \\
& +\beta_{3}(\text { education })_{i}+\beta_{4}(\text { dummy_married })_{i} \\
& +\beta_{5}(\text { dummy_male })_{i} \\
& +\beta_{6}(\text { jobposition })_{i}+\beta_{7}\left({\text { workexperience })_{i}+\beta_{8}(\text { age })_{i}}\right. \\
& +\beta_{9}(\text { dummy_ethnicity })_{i}+\beta_{10}(\text { income })_{i}+\varepsilon_{i}
\end{aligned}
$$

$$
\begin{aligned}
{\text { (intellectual development })_{i}=} & \beta_{0}+\beta_{1}(\text { duration establishment })_{i}+\beta_{2}(\text { dummy_practice })_{i} \\
& +\beta_{3}(\text { education })_{i}+\beta_{4}(\text { dummy_married })_{i} \\
& +\beta_{5}(\text { dummy_male })_{i} \\
& +\beta_{6}(\text { jobposition })_{i}+\beta_{7}(\text { workexperience })_{i}+\beta_{8}(\text { age })_{i} \\
& +\beta_{9}(\text { dummy_ethnicity })_{i}+\beta_{10}(\text { income })_{i}+\varepsilon_{i}
\end{aligned}
$$




$$
\begin{aligned}
\left({\text { spiritual conducts })_{i}=}\right. & \beta_{0}+\beta_{1}(\text { durationestablishment })_{i}+\beta_{2}(\text { dummy_practice })_{i} \\
& +\beta_{3}(\text { education })_{i}+\beta_{4}(\text { dummy_married })_{i}+\beta_{5}(\text { dummy_male })_{i} \\
& +\beta_{6}(\text { jobposition })_{i}+\beta_{7}(\text { workexperience })_{i}+\beta_{8}(\text { age })_{i} \\
& +\beta_{9}(\text { dummy_ethnicity })_{i}+\beta_{10}(\text { income })_{i}+\varepsilon_{i}
\end{aligned}
$$

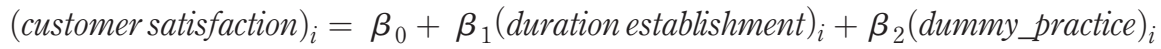

$$
\begin{aligned}
& +\beta_{3}(\text { education })_{i}+\beta_{4}(\text { dummy_married })_{i} \\
& +\beta_{5}(\text { dummy_male })_{i} \\
& +\beta_{6}(\text { jobposition })_{i}+\beta_{7}(\text { workexperience })_{i}+\beta_{8}(\text { age })_{i} \\
& +\beta_{9}(\text { dummy_ethnicity })_{i}+\beta_{10}(\text { income })_{i}+\varepsilon_{i}
\end{aligned}
$$

where $\beta s$ are coefficients of variables, $i$ is a number of respondents and $\xi$ s are errors. The models are tested using the goodness of fit $\left(R^{2}\right), F$-statistic and diagnostic tests of multicollinearity, serial correlation, heteroskedasticity and normal distribution of residuals.

The study also analyzes the correlation between strategies to assess a possible linear association between two continuous variables. It is expected that firms' strategies could be positively or negatively related to each other. The positive and significant relationship between strategies might imply that strategies are a complement to each other and the negative and significant relationship might be interpreted as the existence of a trade-off between two strategies. In this case, Pearson correlation coefficients are calculated and reported.

\section{Results and analyses}

a. Descriptive analysis

Based on data obtained from the survey, it is found that total respondents are almost equally distributed between male and female, that is 50.6 per cent female and 49.4 per cent are male (refer to Table II). The respondents are mostly having an education higher than secondary level and the majority are obtaining first degree level of education. Specifically, 45.9 per cent are having pre-university/diploma level of education and 47.1 per cent is with first degree level. The majority of respondents are married (64.7 per cent) and the most them are at the age of more than 25 years old (97.6 per cent). Majority of respondents is also having work experiences between 6 to 10 years (52.9 per cent) and earn less than RM3000 per month (58.8 per cent) Among them, 27.1 per cent hold the position as a junior executive, 30.6 per cent as a senior executive and 36.5 per cent are managers. As of the firm or company itself, most of the firms are established between 3 to 5 years (30.6 per cent). However, there are quite big number of firms is being in existence for more than 10 years (53 per cent). Majority of them are practicing Islamic activities since Islamic banking and finance is the main focus of the financial sector in Malaysia currently, being one of the world leaders in this financial area.

\section{b. T-test for dependent samples}

Based on the paired samples statistics, the mean scores for spiritual conducts are higher (mean $=100.53, \mathrm{SD}=6.63$ ) compared to the mean scores of technological advance (mean $=26.45$, 
JIABR

Gender

Male

Female

Ethnicity

Malay

Chinese

Indian

others

Religion

Islam

Buddha

Hindu

Christian

Others

Education level

Secondary level

Diploma/pre-university

Bachelor degree

Master degree

$\mathrm{PhD}$

Missing data

Marital status

Single

Married

Age

18-25 years old

26-30 years old

31-35 years old

Above 35

Job position

Junior executive

Senior executive

Manager

30.6

Senior manager

others

Duration of working experiences

Less than 1 year

$1-5$ years

6-10 years

11-20 years

More than 20 years

Monthly income level (of respondent)

Table II.

RM 3,000 and below

Statistics of

RM 3,000-5,000

RM 5,001-10,000

RM 10,001-20,000

Above RM 20,000 


\begin{tabular}{|c|c|c|c|}
\hline & Frequency & $(\%)$ & of firm \\
\hline \multicolumn{4}{|l|}{ Company establishment } \\
\hline Less than 3 years & 1 & 1.2 & \\
\hline $3-5$ years & 26 & 30.6 & \\
\hline 6-10 years & 13 & 15.3 & \\
\hline $11-15$ years & 20 & 23.5 & \\
\hline $16-20$ years & 23 & 27.1 & \\
\hline 21 years and above & 2 & 2.4 & \\
\hline \multicolumn{4}{|l|}{ Company based practice } \\
\hline Islamic & 80 & 94.1 & \\
\hline Conventional & 5 & 5.9 & Table II. \\
\hline
\end{tabular}

$\mathrm{SD}=2.53)$. As shown in Table III, the difference between the means was observed to be statistically significant at 1 per cent level. We also calculate the "effect size" for dependent samples $t$-test using percentage of variance accounted for $\left(r^{2}\right)$ and Eta squared $\left(\eta^{2}\right)$. An effect size is a quantitative measure of the magnitude of a phenomenon. A larger absolute value always indicates a stronger effect. The effect size statistics $\left(r^{2}\right.$ and $\left.\eta^{2}\right)$ provide an indication of the magnitude of differences between the two groups: $r^{2}=\mathrm{t}^{2} /\left(\mathrm{t}^{2}+\mathrm{df}\right)=(-122.65)^{2} /\left((-122.65)^{2}\right.$ $+84)=0.994$ and Eta squared, $\eta^{2}=\mathrm{t}^{2} /\left(\mathrm{t}^{2}+\mathrm{N}-1\right)=0.994$. Base on Cohen (1988, pp. 284-287), as $\eta^{2}$ is greater than 0.14 , it indicates a large effect size.

Similarly, the difference between the means of intellectual development and spirituality conducts was observed to be statistically significant at 1 per cent level. The mean scores for intellectual development is smaller than the mean scores of spirituality conducts by 28.87. The $\eta^{2}$ or $r^{2}$ for this pair is 0.97 which indicates a large effect size. As for pair 3, the mean scores for spiritual conducts (mean $=100.52, \mathrm{SD}=6.64$ ) is higher than mean scores for customer satisfaction concern (mean $=54.47, \mathrm{SD}=4.98$ ). The difference in means of these two scores are significant at 1 per cent based on the $t$ statistics and the effect size is also large $\left(\eta^{2}=0.99\right)$.

The results indicate that the adoption of "spirituality conduct" strategy is ranked at the highest level among firms in studied. Then, it is followed by intellectual development, customer satisfaction and finally, technological advances.

Paired differences

Variable name Mean SD Std error mean $t \quad$ df Sig. (two-tailed)

Pair 1

Scores of technological advance - scores of

spirituality conducts

$\begin{array}{llllll}-74.07 & 5.56 & 0.603 & -122.85 & 84 & 0.000\end{array}$

Pair 2

Scores of intellectual development - scores of spirituality conducts

$\begin{array}{llllll}-28.87 & 4.98 & 0.545 & -53.42 & 84 & 0.000\end{array}$

Pair 3

Scores of spirituality conducts - scores of customer satisfaction concern

Table III.

$t$-test for dependent samples 


\section{c. T-test for independent samples}

Further t-tests are conducted to analyze the existence of significant differences in the mean scores of each strategy when the respondents either male or female, Muslim or non-Muslim, married or single and whether the firm based practice is Islamic or conventional. The null hypotheses for the tests are:

H10. There is no significant difference between male and female responses on scores of each strategy (technological advance, intellectual development, spirituality conducts and customer satisfaction concern).

H20. There is no significant difference between married and single responses on scores of each strategy (technological advance, intellectual development, spirituality conducts and customer satisfaction concern).

H30. There is no significant difference between Muslim and non-Muslim on scores of each strategy (technological advance, intellectual development, spirituality conducts and customer satisfaction concern).

H40. There is no significant difference between Islamic and conventional based-practice firms on scores of each strategy (technological advance, intellectual development, spirituality conducts and customer satisfaction concern).

Results of the $t$-test for equality means scores of technological advance by all four independent variables are displayed in Table IV. As for the firm based practice, those firms, which are adopting Islamic based practice are having lower scores in this strategy (mean = $26.37, \mathrm{SD}=2.24$ ) compared to those firms who adopting conventional based practice (mean $=27.80, \mathrm{SD}=5.72$ ). The output of Levene's test for equality of variance indicates a significant $p$-value of 0.022 , which is smaller than 0.05 . Based on this, estimates from equal variances not assumed are consulted. The results indicate that there is an insignificant difference between the means of scores between these two groups of firms. The effect size statistics provide an indication of the magnitude of differences between the groups within

\begin{tabular}{|c|c|c|c|c|c|c|c|}
\hline \multirow[b]{2}{*}{$\begin{array}{l}\text { Variable name: scores of } \\
\text { technological advance }\end{array}$} & \multicolumn{2}{|c|}{$\begin{array}{l}\text { Levene's test for } \\
\text { Equality of } \\
\text { variances }\end{array}$} & \multirow[b]{2}{*}{$t$} & \multicolumn{3}{|c|}{$t$-test for equality of means } & \multirow[b]{2}{*}{$\begin{array}{l}\text { Std. error } \\
\text { difference }\end{array}$} \\
\hline & $F$ & Sig. & & $\mathrm{df}$ & $\begin{array}{l}\text { Sig. (two- } \\
\text { tailed) }\end{array}$ & $\begin{array}{c}\text { Mean } \\
\text { difference }\end{array}$ & \\
\hline $\begin{array}{l}\text { By based practice (Islamic or co } \\
\text { Equal variances assumed } \\
\text { Equal variances not assumed }\end{array}$ & $\begin{array}{l}\text { entional, } \\
5.47\end{array}$ & 0.022 & $\begin{array}{l}-1.224 \\
-0.555\end{array}$ & $\begin{array}{l}83 \\
4.078\end{array}$ & $\begin{array}{l}0.224 \\
0.608\end{array}$ & $\begin{array}{l}-1.425 \\
-1.425\end{array}$ & $\begin{array}{l}1.164 \\
2.569\end{array}$ \\
\hline $\begin{array}{l}\text { By religion (muslim or non-mus } \\
\text { Equal variances assumed } \\
\text { Equal variances not assumed }\end{array}$ & m) 4.68 & 0.033 & $\begin{array}{l}-1.215 \\
-1.268\end{array}$ & $\begin{array}{l}83 \\
73.28\end{array}$ & $\begin{array}{l}0.228 \\
0.209\end{array}$ & $\begin{array}{l}-0.668 \\
-0.668\end{array}$ & $\begin{array}{l}0.549 \\
0.526\end{array}$ \\
\hline $\begin{array}{l}\text { By gender (male or female) } \\
\text { Equal variances assumed } \\
\text { Equal variances not assumed }\end{array}$ & 0.763 & 0.385 & $\begin{array}{l}0.062 \\
0.062\end{array}$ & $\begin{array}{l}83 \\
73.24\end{array}$ & $\begin{array}{l}0.951 \\
0.950\end{array}$ & $\begin{array}{l}0.034 \\
0.034\end{array}$ & $\begin{array}{l}0.552 \\
0.550\end{array}$ \\
\hline $\begin{array}{l}\text { By marital status (married or } \\
\text { Equal variances assumed } \\
\text { Equal variances not assumed }\end{array}$ & $\begin{array}{l}\text { gle) } \\
0.935\end{array}$ & 0.336 & $\begin{array}{l}1.889 \\
1.747\end{array}$ & $\begin{array}{l}83 \\
47.84\end{array}$ & $\begin{array}{l}0.062 \\
0.087\end{array}$ & $\begin{array}{l}1.069 \\
1.069\end{array}$ & $\begin{array}{l}0.566 \\
0.612\end{array}$ \\
\hline
\end{tabular}

Table IV. Independent sample $t$-test for scores of technological advance by firm basedpractice, religion, gender and marital status of firm representatives

\section{Equal variances assumed}

1.747 
the independent variables. In other words, it is an indication of how much the difference in the dependent variable is influenced by the independent variable. Percentage of variance accounted for $\left(r^{2}\right)$ is computed as $r^{2}=\mathrm{t}^{2} /\left(\mathrm{t}^{2}+\mathrm{df}\right)=-0.555^{2} /\left(-0.555^{2}+4.078\right)=0.070$ of firm (7.02 per cent), which implies that variance of firm based practice moderately explains variances in scores of technological advance. Eta squared computed as $\eta^{2}=\mathrm{t}^{2} /\left(\mathrm{t}^{2}+\left(\mathrm{N}_{1}+\mathrm{N}_{2}\right.\right.$ $-2))=(-0.555)^{2} /\left((-0.555)^{2}+83\right)=0.00369$, which also support the small effect of firm based practice on the mean difference of the scores of technological advance.

Using independent variables of religion, those respondents who are non-Muslims were observed to have slightly higher mean scores of technological advance (mean $=26.82, \mathrm{SD}=$ 1.73) compared to those respondents who are Muslims (mean $=26.15, \mathrm{SD}=3.04$ ). Output of Levene's test for equality of variance indicates a significant $p$-value of 0.033 , that is smaller than 0.05 . Based on this, estimates from equal variances not assumed are consulted. The $t$ test results indicate that there is an insignificant difference between the means of scores of Muslims and non-Muslims. The effect size statistics are computed and the following are the statistics: $r^{2}=0.0215$ (2.15 per cent) and $\eta^{2}=0.0195$ The $r^{2}$ value implies that variance of religion does not largely explain variances in scores of technological advance. Value of $\eta^{2}$ similarly implies the small effect of religion on the mean difference of scores of technological advance.

Using gender as an independent variable, it is found that males have higher mean scores of technological advance (mean $=26.47, \mathrm{SD}=1.99$ ) as compared to females (mean $=26.44$, $\mathrm{SD}=2.99$ ). Output of Levene's test for equality of variance indicates an insignificant $p$-value of 0.385 , which is greater than 0.05 . Thus, estimates from equal variances assumed are referred. The $t$-test results indicate that there is no significant difference between the means of scores of male and female respondents.

By marital status, it is observed that those who are married have slightly higher mean scores $($ mean $=26.83, \mathrm{SD}=2.23$ ) as compared to those who are single $($ mean $=25.76, \mathrm{SD}=$ 2.92). Output of Levene's test for equality of variance indicates an insignificant $p$-value of 0.336 , that is greater than 0.05 . Thus, estimates from equal variances assumed are used. The $t$-test results indicate that there is no significant difference between the means of scores of technological advance between those who are married and single. In sum, findings from the tests indicate that there exist non-significant differences in means of scores of technological advance by religion, gender, marital status and even by the based practice of the firms. Thus, overall, there is no significant difference between the degree of adoption of technological advance strategy among firms who have different based practices and managers with different marital status, religion and gender.

Table $\mathrm{V}$ shows the results of the $t$-test for equality means of scores of intellectual development by all independent variables. Using similar analysis, it is found that there are no significant differences in mean scores of intellectual development strategy by gender, marital status, religion and based practice of firms. Similar results are obtained when scores of spirituality conduct and customer satisfaction concern are used as dependent variables, which can be referred to as Tables VI and VII.

\section{d. Regression analysis}

In this section, a detailed analysis is conducted using multiple regressions by the OLS method to further support our previous findings. In this regression, the dependent variables are scores of technological advance, intellectual development, spirituality conduct and customer satisfaction concern while the regressors (or independent variables) are education level, duration of work experience, job position, monthly income level, years of firms establishment, age, dummy for gender $(1=$ male, $0=$ female), dummy for marital status $(1=$ 
Levene's test for

equality of

variances $\quad t$-test for equality of means

Variable name: scores of $\quad$ Sig. (two- Mean Std. error

$\begin{array}{lllllll}\text { intellectual development } & F & \text { Sig. } & t & \text { df } & \text { tailed) difference difference }\end{array}$

By based practice (Islamic or conventional)

Equal variances assumed $\quad 22.06$

$\begin{array}{llllll}0.000 & 0.217 & 83 & 0.828 & 0.70 & 3.221\end{array}$

Equal variances not assumed

0.000

By religion (Muslim or non-Muslim)

Table V.

By religion (Muslim or non-Muslim)
Equal variances assumed

Independent sample

$t$-test for scores of

intellectual

Equal variances not assumed

3.697

By gender (male or female)

development by firm

based practice,

Equal variances assumed

Equal variances not assumed

5.271

religion, gender and

marital status of firm

By marital status (married or single)

representatives

Equal variances assumed 4.133

Equal variances not assumed

4.133

Equa variances not as uned

\begin{tabular}{|c|c|c|c|c|c|c|c|}
\hline \multirow[b]{2}{*}{$\begin{array}{l}\text { Variable name: scores of spirituality } \\
\text { conducts }\end{array}$} & \multicolumn{2}{|c|}{$\begin{array}{l}\text { Levene's test for } \\
\text { equality of } \\
\text { variances }\end{array}$} & \multicolumn{5}{|c|}{$t$-test for equality of means } \\
\hline & $F$ & Sig. & $t$ & df & $\begin{array}{l}\text { Sig. (two- } \\
\text { tailed) }\end{array}$ & Mean & $\begin{array}{l}\text { Std. error } \\
\text { e difference }\end{array}$ \\
\hline $\begin{array}{l}\text { By based practice (Islamic or conventional) } \\
\text { Equal variances assumed } \\
\text { Equal variances not assumed }\end{array}$ & 11.78 & 0.001 & $\begin{array}{l}1.088 \\
0.508\end{array}$ & $\begin{array}{l}83 \\
4.084\end{array}$ & $\begin{array}{l}0.280 \\
0.638\end{array}$ & $\begin{array}{l}3.325 \\
3.325\end{array}$ & $\begin{array}{l}3.055 \\
6.550\end{array}$ \\
\hline $\begin{array}{l}\text { By religion (Muslim or non-Muslim) } \\
\text { Equal variances assumed } \\
\text { Equal variances not assumed }\end{array}$ & 4.684 & 0.033 & $\begin{array}{l}-0.731 \\
-0.787\end{array}$ & $\begin{array}{l}83 \\
51.37\end{array}$ & $\begin{array}{l}0.467 \\
0.435\end{array}$ & $\begin{array}{l}-1.059 \\
-1.059\end{array}$ & $\begin{array}{l}1.448 \\
1.345\end{array}$ \\
\hline $\begin{array}{l}\text { By gender (male or female) } \\
\text { Equal variances assumed } \\
\text { Equal variances not assumed }\end{array}$ & 4.286 & 0.042 & $\begin{array}{l}1.239 \\
1.252\end{array}$ & $\begin{array}{l}83 \\
47.01\end{array}$ & $\begin{array}{l}0.219 \\
0.217\end{array}$ & $\begin{array}{l}1.777 \\
1.777\end{array}$ & $\begin{array}{l}1.435 \\
1.420\end{array}$ \\
\hline $\begin{array}{l}\text { By marital status (married or single) } \\
\text { Equal variances assumed } \\
\text { Equal variances not assumed }\end{array}$ & 7.512 & 0.008 & $\begin{array}{l}2.089 \\
1.593\end{array}$ & $\begin{array}{l}83 \\
30.93\end{array}$ & $\begin{array}{l}0.040 \\
0.121\end{array}$ & $\begin{array}{l}3.084 \\
3.084\end{array}$ & $\begin{array}{l}1.476 \\
1.936\end{array}$ \\
\hline
\end{tabular}

married, $0=$ single), dummy for ethnicity $(1=$ Malay, $0=$ non-Malay $)$ and dummy for firm based practice $(1=$ Islamic based, $0=$ conventional based). Basically, we would like to observe significant individual contributors to scores of each strategy of firms, as well as overall significant of regressors' variance on the variance of the dependent variable, i.e. the variance of each score of the strategy. Thus, there are 4 models developed in this analysis using scores of each strategy as a dependent variable in each model.

The results of multiple regressions are displayed in Table VIII. In Model 1, using scores of technological advance as the dependent variable, there are four factors contribute 


\begin{tabular}{|c|c|c|c|c|c|c|c|c|}
\hline \multirow[b]{2}{*}{$\begin{array}{l}\text { Variable name: scores of } \\
\text { customer satisfaction concern }\end{array}$} & \multicolumn{2}{|c|}{$\begin{array}{l}\text { Levene's test for } \\
\text { equality of } \\
\text { variances }\end{array}$} & \multirow[b]{2}{*}{$t$} & \multicolumn{3}{|c|}{$t$-test for Equality of Means } & \multirow[b]{2}{*}{$\begin{array}{l}\text { Std. error } \\
\text { difference }\end{array}$} & \multirow[t]{2}{*}{$\begin{array}{r}\text { of firm } \\
\text { of }\end{array}$} \\
\hline & $F$ & Sig & & df & $\begin{array}{l}\text { Sig. (two- } \\
\text { tailed) }\end{array}$ & $\begin{array}{c}\text { Mean } \\
\text { difference }\end{array}$ & & \\
\hline \multicolumn{9}{|c|}{ By based practice (Islamic or conventional) } \\
\hline $\begin{array}{l}\text { Equal variances assumed } \\
\text { Equal variances not assumed }\end{array}$ & 1.812 & 0.182 & $\begin{array}{l}0.771 \\
0.597\end{array}$ & $\begin{array}{l}83 \\
4.287\end{array}$ & $\begin{array}{l}0.443 \\
0.581\end{array}$ & $\begin{array}{l}1.775 \\
1.775\end{array}$ & $\begin{array}{l}2.303 \\
2.973\end{array}$ & \\
\hline $\begin{array}{l}\text { By religion (muslim or non-Musl } \\
\text { Equal variances assumed } \\
\text { Equal variances not assumed }\end{array}$ & m) & 0.050 & $\begin{array}{l}-1.122 \\
-1.199\end{array}$ & $\begin{array}{l}83 \\
56.28\end{array}$ & $\begin{array}{l}0.265 \\
0.235\end{array}$ & $\begin{array}{l}-1.215 \\
-1.215\end{array}$ & $\begin{array}{l}1.083 \\
1.013\end{array}$ & $\begin{array}{r}\text { Table VII. } \\
\text { Independent sample } \\
t \text {-test for scores of }\end{array}$ \\
\hline $\begin{array}{l}\text { By gender (male or female) } \\
\text { Equal variances assumed } \\
\text { Equal variances not assumed }\end{array}$ & 2.912 & 0.092 & $\begin{array}{l}0.227 \\
0.229\end{array}$ & $\begin{array}{l}83 \\
52.12\end{array}$ & $\begin{array}{l}0.821 \\
0.820\end{array}$ & $\begin{array}{l}0.246 \\
0.246\end{array}$ & $\begin{array}{l}1.087 \\
1.077\end{array}$ & $\begin{array}{r}\text { customer satisfaction } \\
\text { concern by firm } \\
\text { based practice, }\end{array}$ \\
\hline $\begin{array}{l}\text { By marital status (married or sin } \\
\text { Equal variances assumed } \\
\text { Equal variances not assumed }\end{array}$ & $\begin{array}{l}\text { gle) } \\
5.042\end{array}$ & 0.027 & $\begin{array}{l}0.915 \\
0.713\end{array}$ & $\begin{array}{l}83 \\
32.14\end{array}$ & $\begin{array}{l}0.363 \\
0.481\end{array}$ & $\begin{array}{l}1.036 \\
1.036\end{array}$ & $\begin{array}{l}1.132 \\
1.454\end{array}$ & $\begin{array}{r}\text { religion, gender and } \\
\text { marital status of firm } \\
\text { representatives }\end{array}$ \\
\hline
\end{tabular}

\begin{tabular}{|c|c|c|c|c|}
\hline Independent variables & $\begin{array}{l}\text { Scores of } \\
\text { technological } \\
\text { advance } \\
\text { (1) }\end{array}$ & $\begin{array}{l}\text { Depend } \\
\text { Scores of } \\
\text { intellectual } \\
\text { development } \\
\text { (2) }\end{array}$ & $\begin{array}{l}\text { Scores of spirituality } \\
\text { conduct } \\
\text { (3) }\end{array}$ & $\begin{array}{l}\text { Scores of customer } \\
\text { satisfaction concern } \\
\text { (4) }\end{array}$ \\
\hline Constant & $26.18 * * *(1.792)$ & $73.201 * * * *(4.835)$ & ) $94.93 * * *(5.06)$ & $52.69 * * * *(3.615)$ \\
\hline Education les & $2.217 * * *(0.449)$ & $4.920 * * * *(1.213)$ & $4.389 * * *(1.269)$ & $4.164 * * * *(0.907)$ \\
\hline Duration of work experience & $0.208(0.497)$ & $-3.562 * * *(1.340)$ & -0.927 (1.403) & $-0.603(1.002)$ \\
\hline & $0.431(0.328)$ & $-1.632 *(0.885)$ & $-0.064(0.927)$ & $-1.264 *(0.662)$ \\
\hline come level & $-1.266 * *(0.530)$ & $3.000 * *(1.429)$ & 0.288 (1.495) & 1.064 (1.068) \\
\hline Years of establishment & $-0.139(0.208)$ & $0.983^{*}(0.561)$ & $-0.222(0.587)$ & $-0.195(0.419)$ \\
\hline Age & $-1.316 * *(0.532)$ & $-1.541(1.436)$ & $-1.847(1.503)$ & $-0.554(1.074)$ \\
\hline Dummy_gender & $0.275(0.513)$ & $-0.764(1.384)$ & $1.473(1.448)$ & $-0.871(1.035)$ \\
\hline my_marital status & $1.246 * *(0.543)$ & 1.230 (1.465) & $2.968 * *(1.533)$ & -0.104 (1.095) \\
\hline Dummy_firm based practice & $-1.910(1.167)$ & $-4.852(3.150)$ & $-0.276(3.297)$ & $-2.717(2.355)$ \\
\hline Dummy_ethnicity & $-0.261(0.502)$ & $0.583(1.354)$ & $0.569(1.417)$ & $-0.254(1.013)$ \\
\hline $\operatorname{Adj} R^{2}$ & & 0.305 & 0.165 & 0.245 \\
\hline$F$ & 4.29 & 4.68 & 2.663 & 3.726 \\
\hline $\operatorname{Prob}(F$-stat $)$ & 0.000 & 0.000 & 0.008 & 0.000 \\
\hline Durbin-Watson & 1.268 & 1.655 & 2.073 & 2.084 \\
\hline
\end{tabular}

Notes: OLS estimates corrected for heteroscedasticity (White and Huber/White, respectively); standard errors are in parentheses; ***statistically significant at the 1 per cent level; **5 per cent level; *10 per cent level

Table VIII.

Results of multiple regressions

significantly to the adoption of technological advance. Those are education level, monthly income level, age and marital status of the firm representative. Education level contributes significantly to the score at 1 per cent level with a positive sign which implies that the higher the level of education of the firm's manager/director, the more strategies adopted in 
technological advance. This result is supported by Quazi and Talukder (2011), who found that educational attainment can also help develop a favorable attitude of employees toward an innovation. Education would enhance the proficiency in network technology and therefore would increase the probability of technology adoption. The negative and significant sign of monthly income coefficient in the model indicates that the adoption of technological advance is more when the monthly income of the manager/director is at a lower level. This implies the importance of adopting technological advances by the firms to improve the performance of firms that later might raise the pay of the employees including the manager which currently at lower levels. The negative and significant sign of age coefficient in a similar model implies that the high adoption of technological advance is proliferating among younger managers as young employees are more vigorous in technological know-how. Kim et al. (2005) did find that younger and well-educated consumers are more likely to adopt new technology. Considering that stably married people are relatively conservative compared to those who choose alternative marital status, i.e. divorced, separated, co-habit or single, married people would be less likely to adopt technology than singles or those with alternative marital status. In Model 1, the coefficient dummy for marital status is significant but with a negative sign. The result indicates that the adoption of technological advance is more among those respondents who are married as compared to single respondents, in contrast to what is expected. As marriage is related to expanding the family size, it is highly expected that married employee links to an expected high level of income. Thus, it is no surprise that the adoption of technology is high among married managers with the expectation that it will improve the performance of the firm and more likelihood the employees' income will rise.

As of Model 2, the dependent variable is the score of intellectual development strategies. From the results displayed, there are five significant factors that contribute significantly to the scores. Among them are education level, working experience, job position and monthly income of manager as well as years of establishment of the firm itself. Similar to technological advance, the education level of manager/respondent significantly affect the scores of intellectual development strategies. The positive sign of the coefficient implies the importance of higher educated managers to be able to address and practice the strategies of intellectual development in the firm. The variable of education level is significant too for the scores of spirituality conduct (in Model 3) and for scores of customer satisfaction concern (in Model 4). Results in Model 2 have also shown that those respondents/managers who have fewer years of working experience and at lower position level are more likely to contribute to the higher scores of intellectual development strategies (the signs for both coefficients of variables are negative). Being young and new in the firm/company, it is expected that the managers are more open-minded and willing to contribute more to the firm in terms of learning and cooperation for the betterment of organization. Variables of the income level of respondents and the firm years of establishment positively contribute to the scores of intellectual development. The significance of these variables construes the fact that higher income received and the secured firm in terms of establishment do matter in promoting the effort of employee to enhance intellectual development. Skills development involves changes in behavior after undergoing a training process. It also changes the way one thinks and be highly motivated. Thus, this will improve work and organization performance (Fisher et al., 1996). Inside the organization/firm, all input components are important for human resource managers in determining the success of businesses. Precisely, skills development programs are very important to increase organization revenues and improve the quality of services. What could be extracted from the current results is that the strategy to adopt the intellectual development in the organization is not only determined by the organizational factors but 
also the individual manager or worker himself. The current findings reveal that managers with high education, well paid, as well as fewer working experience incline more to adopt this strategy.

Results in Model 3, with the scores of spirituality conduct as the outcome variable, have shown that education level and marital status are important predictors to the scores. Other predictors are seemed insignificant. Again, high level of education is important for the spirituality strategy to be adopted in organization. In any organization, individuals require reasoning and judgment based on individuals' principles and beliefs in making choices that balance self-interest against social welfare or claims and responsibilities. Different people who have different principles will make a different decision and the decision made may be a result of an ethical and unethical conducts, which could largely be influenced by his/her level of education. Chambliss (1987) believes that there is the relationship among ethics, education and the formation of a just community and have been central to the Western philosophical tradition classic statement development. Being married, managers are also believed to be more cautious about their conduct particularly among Muslims as working or any activity at work is not only a must to gain a better standard of living for them and family members but also an avenue to gain rewards from God.

Model 4, which concerns on the scores of customer satisfaction, displays another interesting finding that highlights the contribution of high educated managers as well as the lower job position of them to the strategies that concern on customer satisfaction. It is perceived that those who are at a lower position in organization are the one that always deals with customers than those who are at higher positions. Having said that, with good education, they are possible to impose strategies that could improve the satisfaction of the customers and later will prosper the firm and improve its performance. By improving knowledge, instilling values, fostering beliefs and shifting attitudes, education has considerable power to help individuals to be more concern about others.

In general, from the findings, it is found that the based practice of the firm, either Islamic based or conventional based, is not an important factor contribute to all four strategies of the firm to improve its performance. However, education is a very important determinant of all the four strategies adopted by the firms. The importance of education has been emphasized repeatedly in the Qur'an, which is the ultimate source of guidance for Muslims. Verse 20:114 says, "My Lord! Increase me in knowledge." This verse indicates that whatever we know is limited as we need to keep asking Allah to increase our knowledge. Therefore, a Muslim should constantly be seeking more knowledge $(\mathrm{ilm})$. The Qur'an treats knowledge as a means to reaching Iman (faith) for all Muslims. This is demonstrated in the following verses: (Verse 35:28) "Those truly fear God, among His servants, who have knowledge: for God is exalted in Might, Oft-Forgiving." (Verse 39:9) "Are those who know equal to those who do not know? Only they will remember [who are] people of understanding." While knowledge is needed to fulfill religious and spiritual responsibilities, it is also highly important for achieving social and economic development, for well-being of the community, and for ensuring social harmony, freedom and human rights. Thus, Islam endorses education or knowledge as the main factor contributing to intellectual development, technology advances and well-being of others particularly customers faced by firms.

The results are strengthened with the goodness of fit (adjusted $R^{2}$ ), $F$-statistic and diagnostic tests of multicollinearity, serial correlation, heteroskedasticity and normal distribution of residuals. Although adjusted $R^{2}$ in all four models are less than 0.5 (less than 50 per cent), the $F$-statistic is highly significant at 1 per cent level which signifies the importance of variance of each independent variable to the variance of the dependent variable. By examining the variance inflation factors (VIF) and tolerance of predictors, it is 
found that there is no problem of multicollinearity in residuals in each model as each predictor's VIF does not exceed 10 and tolerance figures are quite high (mostly more than 0.8). As of serial correlation, as Durbin-Watson statistic in each model is not less than 1 or greater than 3, it could be concluded that each model suffers no problem of serial correlation. Furthermore, we corrected the model for the heteroskedasticity problem while doing the estimation using the White test. Normality distribution of residuals are ensured by plotting the normal P-P plot and it is found that they are normally distributed as the data mostly fit into the diagonal line.

\section{e. Correlation}

Correlation is the measure of the strength and direction of the relationship between the variables which normally represents by "correlation coefficient." Direction of the relationship can be either positive or negative. Correlations can vary between -1 and 1 . Pearson's product moment correlation coefficient is denoted as $r$ for a sample statistic. It is used when both variables being studied are normally distributed. Results of correlation are presented in Table IX.

Overall, all scores of strategies are positively related between each other but the degree of the relationship varies. It is found that scores of customer satisfaction concern are highly related to spirituality conduct with more than 70 per cent. This reflects a close link between ethics or spiritual act and concern on customer satisfaction in which the spiritual act stresses a lot on giving pleasures to others and tries to avoid self-interest. Ahmad (2003) defines Islam as a set of norms, values and laws that make up the Islamic way of life. The main components of Islam are iman (faith), akhlaq (ethics), and figh, which is the legal rulings that govern the acts of human beings (Mawdudi, 1977). The first two components i.e. iman (faith) and akhlaq (ethics) are the spiritual components, which are permanent and fixed at all times and for all societies. In contrast, the last component that is Fiqh may be modified and changed consistently with time and place. There are at least three types of ethics in society: ethics that are related to individuals, family and society. The concern to the customers is the example of ethics to society. According to Mohammed (2005), the virtue of cooperation, protecting the privacy of others, refraining from gossip, the prohibition of robbery, prohibition of fraud, prohibition of injustice, spreading brotherhood, friendship and love among all members of society are examples of ethics related to society in general. The idea of belief and righteous deeds is mentioned in the Qur'an at least 200 times, emphasizing the importance of what is a "good deed" in the sight of the Divine. In cosmopolitan ethics, all human beings belong to a single community and thus, one should care for the others as a good Samaritan. The same message has been revealed to the Prophet Muhammad, to share

Table IX.

Pearson correlation coefficients

\begin{tabular}{lllll}
\hline & $\begin{array}{c}\text { Technological } \\
\text { advance }\end{array}$ & $\begin{array}{c}\text { Intellectual } \\
\text { development }\end{array}$ & $\begin{array}{c}\text { Spirituality } \\
\text { conduct }\end{array}$ & $\begin{array}{c}\text { Customer } \\
\text { satisfaction } \\
\text { concern }\end{array}$ \\
\hline $\begin{array}{l}\text { Technological advance } \\
\text { Intellectual development }\end{array}$ & 1 & & & \\
$\begin{array}{l}\text { Spirituality conduct } \\
\text { Customer satisfaction concern }\end{array}$ & $0.407^{* * * *}(0.000)$ & 1 & & \\
Note: $p$-value in parentheses & $0.406^{* * * *}(0.000)$ & $0.732^{* * *}(0.000)$ & 1 & \\
\hline
\end{tabular}


with mankind that, in the sight of Allah, the most valuable human being is who acts with a right attitude:

O mankind! We created you from a single (pair) of a male and a female, and made you into nations and tribes, that ye may know each other (not that ye may despise each other). Verily the most honored of you in the sight of Allah is (he who is) the most righteous of you. And Allah has full knowledge and is well acquainted (with all things). (Qur'an 49:13)

When the Qur'an was revealed, it addressed the social needs of the given society in Arabia and its surrounding regions. Its teachings functioned as a compass of ethical behavior and "traits of character or akhlaq" to encourage righteous behavior (Sohani, 2017). Sajoo (2004) comments on the essence of the Islamic value system:

It is incumbent upon the believers to deal with each other in the spirit of the Islamic ethos, which is referred as "akhlaq," values of compassion, charity, wisdom and solidarity.

Correlation coefficient is also found to be high between spirituality conduct and intellectual development scores (73.2 per cent). The strategies of intellectual development such as having innovative ideas, teamwork, handling problem effectively and good communication among staff are somehow the activities that are motivated by good inner feelings or good intentions which simply from the ethical or spiritual dimension of the human being. Nonetheless, spiritually conduct and technological advance scores correlated to more than 50 per cent (58.2 per cent). Though it is not extremely high, the relationship construes the idea that the strategies of technological advances would require the staff to have good conduct such as hardworking, honest, diligent, discipline not only in work but also in performing worship to the creator. These spirituality criteria are complementary to successful research and development as well as innovation in any organization. According to Sohani (2017), the Qur'anic worldview basically accepts that acquisition and understanding of divine knowledge, the intellectual pursuit is important to make wise moral choices and the ethical actions to improve the socio-religious milieu around us. William Chittick, also comments on the classical Islamic philosophical and mystical texts and describes the usage of al- 'aql as a verb. He notes that intellect may imply a restrictive state of reasoning, until unless it is active in the search of knowledge. However, he explains that human intellect, aql, "binds" in the sense of restricting or limiting; there are limits to what human intellect can know, whereas God's truth is unlimited. Chittick (1981) also refers to the saying of the Prophet that 'the first thing created by God was the Intellect'. He suggests that human intellect embodies the characteristics of the "Greatest Spirit' (al-riih al-a'zam) and the 'Supreme Pen' (al-qalam al-a'l)" of the divine. Thus, in this sense, "it possesses a full and direct knowledge of God." Historically, Islamic civilizations has promoted the acquisition of knowledge and the inquiry into nature. This intellectual growth benefitted not only Muslims but also the Jews and Christians, who lived with and around them. These civilizations observed the principles of tolerance and pluralism (Sohani, 2017). Even though scores of intellectual development and customer satisfaction concern have a significant relationship to scores of technological advance, the magnitude is moderate at 40 per cent. It simply implies that any of the two strategies can sometimes be treated as an alternative. A firm could either choose one strategy over another in some cases.

\section{Conclusion}

The spiritual dimension in the theory of the firm was lacking in the past. More attention now focuses on the adoption of a unified theory of the firm by recent studies. From these studies, it could be extracted that there are four main strategies required for firms to be able to 
achieve their main objectives in organizations. Those are technological advances, intellectual development, spirituality conducts and customer satisfaction. The present study attempts to explore the inclination of firms to adopt all these strategies in theory of the firm, what are factors that contribute to the adoption of all these strategies or activities and is there any significant relationship between these strategies of firms in the context of Malaysian firms, particularly in the financial sector.

The study is using a survey to collect primary data from the target respondents, i.e. firms. The responses from the survey are analyzed using several methods: descriptive measures, $t$-test for dependent sample, $t$-test for independent sample, multiple regressions and correlation. The results from multiple regression found that there are four factors contribute significantly to the adoption of technological advance. Those are education level, monthly income level, age and marital status of the firm representative. For the score of intellectual development strategies, there are five significant factors that contribute significantly to the scores. Among them are education level, working experience, job position and monthly income of manager as well as years of establishment of the firm itself. As for the scores of spirituality conduct as the outcome variable, education level and marital status are important predictors to the scores. Other predictors are seemed insignificant. For customer satisfaction concern, the results highlight the contribution of high educated managers as well as the lower job position of them to the strategies. Interestingly, the based practice of firm, either Islamic based or conventional based, is not an important factor contributing to all four strategies of a firm to improve its performance. The correlation results show that all scores of strategies are positively related between each other but the degree of relationship varies. It is found that scores of customer satisfaction concern are highly related to scores of intellectual development and spirituality conduct. The correlation coefficient is also high between spirituality conduct and intellectual development scores.

In sum, the study recognizes the importance of high education among the mangers to enable the firm to adopt all the four strategies in the organization and spirituality dimension in firm activities are not stand alone by itself as it is highly related to intellectual development and even the strategies related to customers.

\section{References}

Abdul Rahman, M.K. and Shamsuddin, A. (2017), "The influence of spiritual capital towards corporate governance practices in Malaysia Top 20 GLCs", International Journal of Business, Economics and Law, Vol. 13 No. 1.

Ahmad, K. (2003), The Challenge of Global Capitalism: An Islamic Perspective. Making Globalization Good: The Moral Challenge of Global Capitalism, Oxford University Press, Oxford.

Akhtar, M.R. (1993), "Modelling the economic growth of an Islamic economy", The American Journal of Islamic Social Sciences, Vol. 10 No. 4, pp. 491-511.

Andreeva, T. and Kianto, A. (2012), "Does knowledge management really matter? Linking knowledge management practices, competitiveness and economic performance", Journal of Knowledge Management, Vol. 16 No. 4, pp. 617-636.

Anderson, E.W. and Sullivan, M.W. (1993), "The antecedents and consequences of customer satisfaction for firms", Marketing Science, Vol. 12 No. 2, pp. 125-143.

Aziz, M.R. (2015), Islamic Banking and Finance in Malaysia: system, Issues and Challenges, USIM Publisher, Negeri Sembilan.

Bernhardt, K.L., Donthu, N. and Kennett, P. (2000), "A longitudinal analysis of satisfaction and profitability”, Journal of Business Research, Vol. 47 No. 2, pp. 161-171. 
Birger, W. (1984), "A resource-based view of the firm”, Strategic Management Journal, Vol. 5 No. 2 , pp. 171-180.

Bolton, R.N. and Drew, J.H. (1991), “A multistage model of customers' assessments of service quality and value", Journal of Consumer Research, Vol. 17 No. 4, pp. 375-384.

Bontis, N., Keow, W.C.C. and Richardson, S. (2000), "Intellectual capital and business performance in Malaysian industries", Journal of Intellectual Capital, Vol. 1 No. 1, pp. 85-100.

Boulescu, M., Ghita, M. and Mares, V. (2002), "Auditul performantei: tehnici de culegere, analiza si interpretare a probelor de audit”, Tribuna Economică, p. 46.

Bryman, A. and Bell, E. (2003), Business Research Methods, Oxford University Press, Oxford.

Cavana, R., Delahaye, B. and Sekaran, U. (2001), Applied Business Research: Qualitative and Quantitative Methods, 3rd ed., John Wiley and Sons, Hoboken, NJ.

Chambliss, J. (1987), Educational Theory as Theory of Conduct: From Aristotle to Dewey, State Univ, New York, NY.

Chittick, W.C. (1981), "Mysticism versus philosophy in earlier Islamic history: the Al- Tūsi, Al-Qūnawi correspondence”, Religious Studies, Vol. 17 No. 1, pp. 87-104.

Cronbach, L.J. (1946), "A case study of the split-half reliability coefficient”, Journal of Educational Psychology, Vol. 37 No. 8, pp. 473-480.

Coase, R.H. (1937), “The nature of the firm”, Economica, Vol. 4 No. 16, pp. 386-405.

Coase, R.H. (1960), "The problem of social cost", The Journal of Law and Economics, Vol. 3, pp. 1-44.

Coase, R.H. (1988), "The nature of the firm: meaning", The Journal of Law, Economics, and Organization, Vol. 4, pp. 19-32.

Grine, F., Fares, D. and Meguellati, A. (2015), "Islamic spirituality and entrepreneurship: a case study of women entrepreneurs in Malaysia", The Journal of Happiness and Well-Being, Vol. 3 No. 1, pp. 41-56.

Djafri, F. and Noordin, K. (2017), "The impact of workplace spirituality on organizational commitment: a case study of Takaful agents in Malaysia”, Humanomics, Vol. 33 No. 3, pp. 384-396.

Fisher, J.D., Fisher, W.A., Misovich, S.J., Kimble, D.L. and Malloy, T.E. (1996), "Changing AIDS risk behaviour: effects of an intervention emphasising AIDS risk reduction information, motivation and behavioral skills in a college population", Health Psychology, Vol. 15 No. 2, pp. 114-123.

Foss, N.J. (2000), "The theory of the firm: an introduction to themes and contributions", in Foss, N.J. (Ed.), The Theory of the Firm. Critical Perspectives on Business and Management, Routledge, London, pp. 15-61.

Garrouste, P. and Saussier, S. (2005), "Looking for a theory of the firm: future challenges", Journal of Economic Behavior and Organization, Vol. 58 No. 2, pp. 178-199.

Guion, R.M. (1980), "On trinitarian doctrines of validity”, Professional Psychology, Vol. 11 No. 3, pp. 385-398.

Hair, J., Black, W., Babin, B., Anderson, R. and Tatham, R. (2006), Multivariate Data Analysis, 6th ed., Pearson Prentice Hall, Upper saddle River, N.J.

Hasan, Z. (2002), "Maximizing postulates and their efficacy for Islamic economics", American Journal of Islamic Social Sciences, Vol. 19 No. 1, pp. 95-118.

Hassan, M.U. (2010), "Islamic approach of economics: some discourses on Khurshid Ahmad's vision of socio-economic order, self-reliance and economic development", Kyoto Bulletin of Islamic Area Studies, Vols 3/2, pp. 216-240.

Inkinen, H. (2015), "Review of empirical research on intellectual capital and firm performance", Journal of Intellectual Capital, Vol. 16 No. 3, pp. 518-565.

Heskett, J.L., Sasser, W.E. and Schlesinger, L.A. (1994), The Service Profit Chain: How Leading Companies Link Profit and Growth to Loyalty, Satisfaction, and Value, Free Press, New York, NY. 
Ittner, C.D. and Larcker, D.F. (1998), "Are non-financial measures leading indicators of financial performance? An analysis of customer satisfaction", Journal of Accounting Research, Vol. 36, pp. $1-46$.

Karim, N.S. and Hussein, R. (2008), "Managers' perception of information management and the role of information and knowledge managers: the Malaysian perspectives", International Journal of Information Management, Vol. 28 No. 2, pp. 114-127.

Kay, N. (1992), "Markets, false hierarchies and the evolution of the modern corporation", Journal of Economic Behavior and Organization, Vol. 17 No. 3, pp. 315-333.

Kerin, R.A., Mahajan, V. and Varadarajan, P.R. (1990), Contemporary Perspectives on Strategic Market Planning, Prentice-Hall, Englewood Cliffs, NJ.

Kharuddin, S., Zariyawati, M.A. and Annuar, M.N. (2010), "Information system and firms' performance: the case of Malaysian small medium enterprises", International Business Research, Vol. 3 No. 4 , pp. 28-35.

Kim, B.M., Richard, W. and Tansel, Y. (2005), "The determinants of consumers' adoption of internet banking”, Conference Series; [Proceedings], Federal Reserve Bank of Boston.

Kogut, B. and Zander, U. (1996), "What firms do? Coordination, identity, and learning", Organization Science, Vol. 7 No. 5, pp. 502-518.

Lam, S.Y., Shankar, V., Erramilli, M.K. and Murthy, B. (2004), "Customer value, satisfaction, and switching costs: an illustration from business-to-business service context", Journal of the Academy of Marketing Science, Vol. 32 No. 3, pp. 293-311.

Langlois, R. and Garrouste, P. (1997), "Cognition, redundancy, and learning in organisations", Economics of Innovation and New Technology, Vol. 4 No. 4, pp. 287-299.

Lewis, H. (2006), Excellence Without a Soul: How a Great University Forgot Education, Public Affairs, New York, NY.

Liu, P.L., Chen, W.C. and Tsai, C.H. (2004), "An empirical study on the correlation between knowledge management capability and competitiveness in Taiwan's industries", Technovation, Vol. 24 No. 12, pp. 971-977.

Mahutga, M.C. and Smith, D.A. (2011), "Globalization, the structure of the world economy and economic development”, Social Science Research, Vol. 40 No. 1, pp. 257-272.

Mawdudi (1977), Life's System in Islam, 7th ed., Darul Al-Ressalh Publication, Beirut.

Mittal, V. and Kamakura, W.A. (2001), "Satisfaction, repurchase intent and repurchase behavior: investigating the moderating effect of customer characteristics", Journal of Marketing Research, Vol. 38 No. 1, pp. 131-142.

Mohammed, A. (2005), "The relationship between Islamic rules and accountants' ethics", Unpublished Manuscript, Hadhramout, Yemen.

Morgan, N.M. and Rego, L.L. (2006), "The value of different customer satisfaction and loyalty metrics in predicting business performance", Marketing Science, Vol. 25 No. 5, pp. 426-431.

Nelson, R.R. and Winter, S.G. (1982), An Evolutionary Theory of Economic Change, Cambridge University Press, New York, NY.

Norusis, M. (2002), SPSS11.0 Guide to Data, Prentice Hall, Upper Saddle River, NJ.

Osman-Gani, A. and Sarif, S.M. (Eds) (2011), Spirituality in Management from Islamic Perspective, IIUM Press, Kuala Lumpur.

Palacios Marqués, D. and Garrigós-Simón, F.J. (2006), “The effect of knowledge management practices on firm performance", Journal of Knowledge Management, Vol. 10 No. 3, pp. 143-156.

Park, H.Y. and Shin, G.C. (2004), The Grand Unified Theory of the Firmsnd Corporate Strategy: measures to Build Corporate Competitiveness, Korean Economic Research Institute, Seoul.

Reichheld, F.F. and Sasser, W.E. Jr. (1990), "Zero defections: quality comes to services", Harvard Business Review, Vol. 68 No. 5, pp. 105-111. 
Quazi, A. and Talukder, M. (2011), "Demographic determinants of adoption of technological innovation", Journal of Computer Information Systems, Vol. 52 No. 1, pp. 34-42.

Sajoo, A.B. (2004), Muslim Ethics: Emerging Vistas, I.B. Tauris Publishers, London.

Unified theory of firm

Sarif, S.M. (2013), "Utilitarianism approach in ethical decision making among Malaysian social entrepreneurs", in Roosfa, H. and Abdul Ghafar, I. (Eds), Proceeding for Research Findings Seminar on Higher Education Sector 2013, Vol. 2, pp. 1134-1140.

Sarif, S.M., Sarwar, A. and Ismail, Y. (2013), "Practice of social entrepeneurship among the Muslim entrepreneurs in Malaysia”, Middle-East Journal of Scientific Research, Vol. 14 No. 11, pp. 1463-1470.

Sarah, K., Andrew, S., Georg, K. and Charles, W. (2001), "Knowledge-based theories of the firm in strategic management: a review and extension”, Massachusetts Institute of Technology Sloan Working Paper \#4216-01 February 1, 2001.

Lee, S.P. and Mohammed, S. (2014), "Intellectual capital on listed agricultural firms' performance in Malaysia", International Journal of Learning and Intellectual Capital, Vol. 11 No. 3.

Sohani, A. (2017), "The intellectual, ethical, and, spiritual dimensions of the Islamic thought", Honors Theses.

Tsafe, B.M. and Rahman, R.A. (2013), "Effects of spirituality on board performance in Malaysian microfinance firms", Middle East Journal of Scientific Research, Vol. 18 No. 5, pp. 675-688.

Vergragt, P.J. (2012), "Technology, globalization, and sustainable development”, Journal of Cleaner Production, Vol. 24, pp. 204-206.

Walker, P. (2008), "The (non) theory of the knowledge firm", Working Papers in Economics 08/07, University of Canterbury, Department of Economics and Finance.

Zsolnai, L. (2015), "Spirituality, ethics and sustainability", in Zsolnai, L. (Eds) The Spiritual Dimension of Business Ethics and Sustainability Management, Springer International Publishing, Switzerland, pp. 3-11.

\section{Further reading}

Akhtar, M.R. (1992), "An Islamic framework for employer-employee relationships", The American Journal of Islamic Social Sciences, Vol. 9 No. 2, pp. 202-218.

Bendjilali, B. and Taher, F.B. (1990), “A zero efficiency loss monopolist: an Islamic perspective”, The American Journal of Islamic Social Sciences, Vol. 7 No. 1, pp. 219-232.

Intan Salwani, M., Marthandan, G., Daud Norzaidi, M. and Choy Chong, S. (2009), "E-commerce usage and business performance in the Malaysian tourism sector: empirical analysis", Information Management and Computer Security, Vol. 17 No. 2, pp. 166-185.

Stuart, L.H. (1995), “A natural-resource- based view of the firm”, Academy of Management Review, Vol. 20 No. 4, pp. 986 -1014.

Zainal, M., Rose, R.C., Abdullah, I. and Masrom, M. (2005), "The relationship between information technology acceptance and organizational agility in Malaysia”, Information and Management, Vol. 42, pp. 829-839.

\section{Corresponding author}

Jarita Duasa can be contacted at: jarita@iium.edu.my

For instructions on how to order reprints of this article, please visit our website:

www.emeraldgrouppublishing.com/licensing/reprints.htm

Or contact us for further details: permissions@emeraldinsight.com 